\title{
Preceding Maize Crop Herbicide Residual Effect on Germination, Growth and Vigour of Succeeding Blackgram
}

\author{
R. Arockia Infant Paul', G. Srinivasan², A. Veeramani ${ }^{1}$, R. Thamizh Vendan ${ }^{3}$
}

10.18805/IJARe.A-5810

\begin{abstract}
Background: Weeds are the most critical pest, which cause the highest yield reduction in food grain crops. Weeds interfere with maize growth by competing one or more growth limiting factors, controlling of weeds in maize during the critical period assumes great importance for realizing higher yield. Unavailability of relatively cheap labour in time necessitated the use of herbicides in maize. Residual impact of herbicides caused significant influence on germination and growth of succeeding crop.

Methods: The field experiment was carried out during kharif 2019 at Agricultural College and Research Institute, Madurai to evaluate the residual effect of herbicides used in preceding maize on succeeding blackgram. Treatments were application of pre emergence herbicide atrazine at $0.25 \mathrm{~kg} \mathrm{ha}^{-1}$ or pendimethalin $1 \mathrm{~kg} \mathrm{ha}^{-1}$ applied singly on 3 days after sowing and in combination with post emergence herbicide tembotrione $120 \mathrm{~g} \mathrm{ha}^{-1}$ or halosulfuron methyl $90 \mathrm{~g} \mathrm{ha}^{-1}$ on 25 DAS, weed free check, unweeded check in maize crop. Result: Among the weed control treatments, pre emergence herbicides atrazine $0.25 \mathrm{~kg} \mathrm{ha}^{-1}$ or pendimethalin $1 \mathrm{~kg}^{-1}$ singly and in combination with post emergence herbicides tembotrione $120 \mathrm{~g} \mathrm{ha}^{-1}$ or halosulfuron methyl $90 \mathrm{~g} \mathrm{ha}^{-1}$ applied in maize crop did not caused any phyotoxicity and residual impact on succeeding blackgram. However, the highest plant height $(29.5 \mathrm{~cm})$, dry matter production (1.17 $\mathrm{g} \mathrm{plant}^{-1}$ ) and seedling vigour index (1473) of succeeding blackgram was recorded in atrazine at $0.25 \mathrm{~kg}^{-1}$ as pre emergence at 3 DAS followed by tembotrione at $120 \mathrm{~g} \mathrm{ha}^{-1}$ as post emergence at 25 DAS.
\end{abstract}

Key words: Blackgram, Phytotoxicity, Residual impact, Seedling vigour index.

\section{INTRODUCTION}

Weeds are the most inevitable plants exist on the earth before man started cultivation of crops. Weeds are the most underestimated crop pests, which cause higher reduction in yield of crop than other pest and diseases. Weeds caused $45 \%$ of total annual loss of agricultural produce in India (Yaduraju, 2015). During early stages, weeds compete with crop for light, space, water, nutrients and weed reduces the photosynthetic efficiency, dry matter production and partitioning of food material from source to sink resulting in drastic yield reduction (Korav et al., 2018).

Maize is one of the pivotal food grain crop in the world and it have the highest genetic yield potential among cereals. In India more than $80 \%$ of maize was grown during kharif season. The productivity of maize is low in India as compared to world productivity, which can be attributed to several limiting factors (USDA, 2020). Among all, weed infestation and poor weed management practices poses severe yield reduction and it contributes a significant role in deciding the crop yield. Losses caused by weeds vary due to wider adaptation of soil and climatic condition. The average loss in grain yield by weeds in maize was reported to be 18 to $65 \%$ (Gharde et al., 2018). Controlling of weeds in maize during the critical period assumes great importance for realizing higher yield. If weeding delayed beyond the critical period, yield losses caused by weeds were irrevocable. Poor weed control results increased weed seed bank on soil and sustained the life cycle of weeds on next season. Unavailability of relatively cheap labour in time necessitated the use of herbicides in maize. Pre emergence application
1Department of Agronomy, Agricultural College and Research Institute, Tamil Nadu Agricultural University, Madurai-625 104, Tamil Nadu, India.

${ }^{2}$ ICAR-Krishi Vigyan Kendra, Aruppukottai-626 107, Tamil Nadu, India.

${ }^{3}$ Department of Agricultural Microbiology, Agricultural College and Research Institute, Tamil Nadu Agricultural University, Madurai625 104, Tamil Nadu, India.

Corresponding Author: R. Arockia Infant Paul, Department of Agronomy, Agricultural College and Research Institute, Tamil Nadu Agricultural University, Madurai-625 104, Tamil Nadu, India.

Email: rainfantpaul@gmail.com

How to cite this article: Paul, R.A.I., Srinivasan, G., Veeramani, A. and Vendan, R.T. (). Preceding Maize Crop Herbicide Residual Effect on Germination, Growth and Vigour of Succeeding Blackgram. Indian Journal of Agricultural Research. DOI: 10.18805/ IJARe.A-5810.

Submitted: 30-04-2021 Accepted: 28-07-2021 Online: 26-08-2021

of herbicides do not give fruitful control of late emerging weeds. In such a condition, sequential application of herbicides provide broad spectrum weed control during critical period of the crop.

Volume of herbicides consumed in India is about 3290.87 M T (Indiastat, 2019). Each herbicides have some significant half self-life on soil environment and it have significant impact on succeeding crop. Shrinking in land area force intensive cultivation practices, which shorten the waiting period of succeeding crop. 
Fertility restoration is a major reason for inclusion of cereals-pulses cropping system (Adarsh et al., 2019). Residual herbicides caused significant influence on crop growth and germination. If residue of herbicide may persist in the soil, the vigor of the non-target succeeding crops can be reduced (Houge and Neilsen, 1988). Pre-emergence application of atrazine $1.12 \mathrm{~kg} \mathrm{ha}^{-1}$ and mesotrione $280 \mathrm{~g}$ $\mathrm{ha}^{-1}$ significantly affected the dry weight and yield of vegetable crops even after one year on sandy loam soils (Robinson, 2008).

Residual phytotoxicity of the herbicide behavior in the environment has been investigated by using sensitive crops (Horowritz, 1976). Pulses are highly sensitive to residual herbicides. Acquire the knowledge of herbicides in cropping system is a key factor for successful crop production in cropping system. In this contract, selecting the suitable weed management practices in cropping system to achieve ecologically and economically productive to farmers and does not cause any residual effect on succeeding pulse crop.

\section{MATERIALS AND METHODS}

\section{Experiment I}

\section{Experimental site and soil analysis}

Field experiment was designed at Department of Agronomy, Agricultural College and Research Institute, Tamil Nadu Agricultural University - Madurai. The experiment was conducted during kharif season of 2019 to study the residual effect of sequential application of herbicides on maizeblackgram cropping system. The experimental field was geographically situated between $9^{\circ} .54^{\prime} \mathrm{N}$ latitude and $78^{\circ} .54^{\prime}$ E longitude with an altitude of 147 meters above the mean sea level, which will comes under the southern agro climatic zone of Tamil Nadu. The soil was sandy clay loam in nature with $\mathrm{pH}$ of 7.65 . The initial soil contain medium amount of nitrogen and phosphorus content $\left(272\right.$ and $16 \mathrm{~kg} \mathrm{ha}^{-1}$ respectively) and high amount of potassium (353 $\left.\mathrm{kg} \mathrm{ha}^{-1}\right)$. The organic carbon content of the soil was $0.48 \%$.

\section{Experiment details}

The experiment was laid out in randomized block design with three replications. The gross plot size of the experimental site was $24 \mathrm{~m}^{2}(6 \mathrm{~m} \times 4 \mathrm{~m})$. The treatments comprised of $T_{1}$ - Atrazine $50 \mathrm{WP}$ at $0.25 \mathrm{~kg} \mathrm{ha}^{-1}$ as pre emergence at 3 DAS followed by one hand weeding at 25 DAS, $\mathrm{T}_{2}-$ Pendimethalin $38.7 \mathrm{EC}$ at $1 \mathrm{~kg} \mathrm{ha}^{-1}$ as pre emergence at 3 DAS followed by one hand weeding at 25 DAS, $\mathrm{T}_{3}$ - Atrazine $50 \mathrm{WP}$ at $0.25 \mathrm{~kg} \mathrm{ha}^{-1}$ as pre emergence at 3 DAS followed by tembotrione $34.4 \mathrm{SC}$ at $120 \mathrm{~g} \mathrm{ha}^{-1}$ as post emergence at $25 \mathrm{DAS}, \mathrm{T}_{4}$ - Pendimethalin $38.7 \mathrm{EC}$ at 1 $\mathrm{kg} \mathrm{ha}^{-1}$ as pre emergence at 3 DAS followed by tembotrione $34.4 \mathrm{SC}$ at $120 \mathrm{~g} \mathrm{ha}^{-1}$ as post emergence at $25 \mathrm{DAS}, \mathrm{T}_{5}^{-}$ Atrazine $50 \mathrm{WP}$ at $0.25 \mathrm{~kg} \mathrm{ha}^{-1}$ as pre emergence at 3 DAS followed by halosulfuron methyl $75 \mathrm{WG}$ at $90 \mathrm{~g} \mathrm{ha}^{-1}$ as post emergence at 25 DAS, $\mathrm{T}_{6}$ - Pendimethalin $38.7 \mathrm{EC}$ at $1 \mathrm{~kg}$ $\mathrm{ha}^{-1}$ as pre emergence at 3 DAS followed by halosulfuron methyl $75 \mathrm{WG}$ at $90 \mathrm{~g} \mathrm{ha}^{-1}$ as post emergence at 25 DAS, $\mathrm{T}_{7}$ - weed free check and $\mathrm{T}_{8}$ - unweeded check.

\section{Agronomic practices}

TNAU maize hybrid Co- 6 was used as a test variety for the experimentation. Healthy and viable maize seed were dibbled on the side of the ridges by adopting a spacing of $60 \times 25 \mathrm{~cm}$. The recommended dose of fertilizers for irrigated condition (250:75:75 kg NPK ha-1) were applied in the form of urea, single super phosphate and muriate of potash. The entire dose of phosphorus and potassium and 25\% nitrogen were applied as basal. Remaining $50 \% \mathrm{~N}$ and $25 \% \mathrm{~N}$ was top dressed at 25 and 45 days after sowing. Irrigation was scheduled on need basis at an interval of 7 to 10 days.

\section{Experiment II}

After harvesting of maize crop the undisturbed soil samples were collected by scrapping the upper layer of soil $(10 \mathrm{~cm})$ and shade dried. The dried soil was taken at the rate of 2.0 $\mathrm{kg}$ per plot. Ten blackgram seeds were sown pot $^{-1}$ at $5 \mathrm{~cm}$ depth and periodically watered. In the experiment VBN 3 blackgram variety was used as a test variety. Fertilizers was not applied to the pot, it helps to observe the impact of weeds on vigour of succeeding crop growth.

\section{Biometrics observation}

Germination percentage, shoot length, root length and seedling vigour index (SVI) was observed at 10 DAS. Germination percentage and SVI were calculated using the following formulae.

$$
\begin{aligned}
& \text { Germination percentage }= \\
& \frac{\text { number of germinated seeds }}{\text { total number of seeds }} \times 100 .
\end{aligned}
$$

(Ellis and Roberts, 1981)

Seedling vigour index $=$

Germination percentage $x$ (root length + shoot length)

(Abdul-Baki and Anderson, 1973).

Three number of blackgram seedlings were left over the pot and remaining seedlings were thinned out and used for analyse the shoot and root length. Plant dry matter production, plant height, number of leaves and number of root nodules were observed at 30 DAS. The extended weed control of herbicides on succeeding crop was observed at 15 DAS. The density and dry weight of weeds associated with blackgram at 15 DAS were recorded. The phytotoxic effect of preceding herbicides on succeeding crop was recorded. The symptom of injury was graded with ten point scale based on the percentage of injury (Rao, 1983). The toxicity scales were furnished in Table 1.

\section{Statistical analysis}

The data on different parameters were analyzed statistically by adopting Fisher's method of ANOVA suggested by Gomez and Gomez (1984). The data on weed density and weed dry weight were subjected to square root transformation 
Preceding Maize Crop Herbicide Residual Effect on Germination, Growth and Vigour of Succeeding Blackgram

$(\sqrt{ } \mathrm{x}+0.5)$ and germination percentage was subjected to arcsine transformation before analysis. The collected data was compared by LSD using SPSS.

\section{RESULTS AND DISCUSSION}

\section{Phytotoxicity}

Application of pre emergence (atrazine, pendimethalin) and post emergence (tembotrione, halosulfuron methyl) herbicides singly and their combinations in maize did not cause any phytotoxic residual effect in succeeding blackgram variety VBN 3 (Table 2).

\section{Germination parameters}

The data on germination parameters such as germination percentage, shoot, root length and seedling vigour index of blackgram are presented in Table 3. Pre emergence application of atrazine or pendimethalin singly and in combination with post emergence tembotrione or halosulfuron methyl had no significant effect on germination of blackgram. Germination percentage of blackgram was not influenced by any of the weed management practices imposed to preceding maize crop. Application of recommended dose of herbicides did not showed any residual impact on succeeding crop. This was in line with Verma et al. (2009) and Singh et al. (2014).

The data pertaining to root and shoot length at 10 DAS showed significantly different among the treatments. The highest root length $(8.34 \mathrm{~cm})$ and shoot length $(10.37 \mathrm{~cm})$

Table 1: Phytotoxicity rating.

\begin{tabular}{ll}
\hline Rating & Effect on crop \\
\hline 0 & No injury \\
1 & Slight stunting \\
2 & Some stand lost, stunting or discoloration \\
3 & Injury more pronounced but not persistent \\
4 & Moderate injury, recovery possible \\
5 & Injury more persistent, recovery doubtful \\
6 & Near severe injury, no recovery possible \\
7 & Severe injury, stand loss \\
8 & Almost destroyed, a few plants surviving \\
9 & Very few plants alive \\
10 & Complete destruction \\
\hline
\end{tabular}

was recorded in weed free check and it was on par with pre emergence atrazine at $0.25 \mathrm{~kg} \mathrm{ha}^{-1}$ followed by post emergence tembotrione at $120 \mathrm{~g} \mathrm{ha}^{-1}$.

Seedling vigour index (SVI) indicated the magnitude of effective utilization of resources from existing resource pool. SVI was influenced by different weed management practices used in preceding maize crop. The highest values was recorded in weed free check (1627) and was followed by pre emergence atrazine at $0.25 \mathrm{~kg} \mathrm{ha}^{-1}$ followed by post emergence tembotrione at $120 \mathrm{~g} \mathrm{ha}^{-1}$. This might be due to the better weed control efficiency as a result of lower dry matter production of weeds which restricted the nutrient depletion by weeds in preceding maize field supports the nutrient availability to succeeding crop helps superior shoot and root length in treated pots over untreated pots. This was agreement with findings of Chand et al. (2014) and Nazreen et al. (2018).

\section{Observation on weeds}

The data on weed density and weed dry weight was presented in Table 4. The sequential application of herbicides effectively controlled the weeds in maize crop and recorded the extended weed control upto early stages of succeeding blackgram. The lowest density (5.33 number pot $\left.^{-1}\right)$ and dry weight (2.72 $\left.\mathrm{g} \mathrm{pot}^{-1}\right)$ of weeds associated with succeeding blackgram was recorded in sequential application of atrazine $0.25 \mathrm{~kg} \mathrm{ha}^{-1}$ followed by tembotrione $120 \mathrm{~g} \mathrm{ha}^{-1}$ imposed to preceding maize crop. It might be application of atrazine effectively controlled the early stages of weed and tembotrione controlled the second flush weeds. Both herbicides inhibit the weeds before seed set and reduced the quantum of weed seed bank persistence in the soil and reduce the weed emergence on succeeding crop season. Effective control of weeds before onset of flowering in preceding crop reduce the weed seed bank in soil and provided congenial atmosphere to succeeding blackgram for efficient utilization of natural resources. These result is in accordance with the earlier findings of Dekker (2015).

\section{Growth parameters}

The growth parameters (plant height, number of leaves, dry matter production and number of root nodules) were recorded and presented in Table 5 . The recorded results showed that the highest growth parameters of blackgram

Table 2: Phytotoxicity rating of residual herbicide on succeeding blackgram.

\begin{tabular}{|c|c|}
\hline Treatments & Phytotoxicity rating \\
\hline Atrazine $50 \mathrm{WP}\left(0.25 \mathrm{~kg} \mathrm{ha}^{-1}\right)$ at 3 DAS followed by one hand weeding at 25 DAS & 0 \\
\hline Pendimethalin $38.7 \mathrm{EC}\left(1 \mathrm{~kg} \mathrm{ha}^{-1}\right)$ at 3 DAS followed by one hand weeding at 25 DAS & 0 \\
\hline Atrazine $50 \mathrm{WP}\left(0.25 \mathrm{~kg} \mathrm{ha}^{-1}\right)$ at 3 DAS followed by tembotrione $34.4 \mathrm{SC}\left(120 \mathrm{~g} \mathrm{ha}^{-1}\right)$ at $25 \mathrm{DAS}$ & 0 \\
\hline Pendimethalin $38.7 \mathrm{EC}\left(1 \mathrm{~kg} \mathrm{ha}^{-1}\right)$ at $3 \mathrm{DAS}$ followed by tembotrione $34.4 \mathrm{SC}\left(120 \mathrm{~g} \mathrm{ha}^{-1}\right)$ at $25 \mathrm{DAS}$ & 0 \\
\hline Atrazine $50 \mathrm{WP}\left(0.25 \mathrm{~kg} \mathrm{ha}^{-1}\right)$ at $3 \mathrm{DAS}$ followed by halosulfuron methyl $75 \mathrm{WG}\left(90 \mathrm{~g} \mathrm{ha}^{-1}\right)$ at $25 \mathrm{DAS}$ & 0 \\
\hline Pendimethalin $38.7 \mathrm{EC}\left(1 \mathrm{~kg} \mathrm{ha}^{-1}\right)$ at 3 DAS followed by halosulfuron methyl $75 \mathrm{WG}\left(90 \mathrm{~g} \mathrm{ha}^{-1}\right)$ at $25 \mathrm{DAS}$ & 0 \\
\hline Weed free check & 0 \\
\hline Unweeded check & 0 \\
\hline
\end{tabular}

*Data are not statistically analysed 
Preceding Maize Crop Herbicide Residual Effect on Germination, Growth and Vigour of Succeeding Blackgram

was recorded in weed control treatments over unweeded check. Nutrient depletion from the soil is a function of dry weight and nutrient content of weed biomass. Application of herbicides restricted the removal of nutrient by weeds at preceding maize crop, it maintain the nutrient availability to succeeding blackgram and favour the seedlings growth and development. Quantity of nutrient availability in succeeding crop is the reflection of biomass production. The highest

Table 3: Effect of residual herbicides on succeeding blackgram germination parameters.

\begin{tabular}{|c|c|c|c|c|}
\hline Treatments & $\begin{array}{c}\text { Germination } \\
\text { percentage } \\
(\%)\end{array}$ & $\begin{array}{c}\text { Shoot } \\
\text { length } \\
(\mathrm{cm})\end{array}$ & $\begin{array}{l}\text { Root } \\
\text { length } \\
(\mathrm{cm})\end{array}$ & $\begin{array}{c}\text { Seedling } \\
\text { vigour } \\
\text { Index }\end{array}$ \\
\hline $\begin{array}{l}\text { Atrazine } 50 \text { WP }\left(0.25 \mathrm{~kg} \mathrm{ha}^{-1}\right) \text { at } 3 \text { DAS followed by one } \\
\text { hand weeding at } 25 \mathrm{DAS}\end{array}$ & $\begin{array}{c}67.2^{*} \\
(85.0)^{\star *}\end{array}$ & 9.47 & 6.90 & 1442 \\
\hline $\begin{array}{l}\text { Pendimethalin } 38.7 \text { EC }\left(1 \mathrm{~kg} \mathrm{ha}^{-1}\right) \text { at } 3 \text { DAS followed by one } \\
\text { hand weeding at } 25 \text { DAS }\end{array}$ & $\begin{array}{c}66.5^{*} \\
(84.0)^{* *}\end{array}$ & 9.34 & 6.63 & 1456 \\
\hline $\begin{array}{l}\text { Atrazine } 50 \text { WP }\left(0.25 \mathrm{~kg} \mathrm{ha}^{-1}\right) \text { at } 3 \text { DAS followed by } \\
\text { tembotrione } 34.4 \mathrm{SC}\left(120 \mathrm{~g} \mathrm{ha}^{-1}\right) \text { at } 25 \mathrm{DAS}\end{array}$ & $\begin{array}{c}67.4^{*} \\
(84.7)^{* *}\end{array}$ & 9.99 & 8.00 & 1473 \\
\hline $\begin{array}{l}\text { Pendimethalin } 38.7 \mathrm{EC}\left(1 \mathrm{~kg} \mathrm{ha}^{-1}\right) \text { at } 3 \text { DAS followed by } \\
\text { tembotrione } 34.4 \mathrm{SC}\left(120 \mathrm{~g} \mathrm{ha}^{-1}\right) \text { at } 25 \mathrm{DAS}\end{array}$ & $\begin{array}{l}65.7^{*} \\
(83.0)^{\star *}\end{array}$ & 9.68 & 7.68 & 1467 \\
\hline $\begin{array}{l}\text { Atrazine } 50 \mathrm{WP}\left(0.25 \mathrm{~kg} \mathrm{ha}^{-1}\right) \text { at } 3 \text { DAS followed by } \\
\text { halosulfuron methyl } 75 \mathrm{WG}\left(90 \mathrm{~g} \mathrm{ha}^{-1}\right) \text { at } 25 \text { DAS }\end{array}$ & $\begin{array}{l}67.0^{*} \\
(84.7)^{* *}\end{array}$ & 9.67 & 7.48 & 1401 \\
\hline $\begin{array}{l}\text { Pendimethalin } 38.7 \mathrm{EC}\left(1 \mathrm{~kg} \mathrm{ha}^{-1}\right) \text { at } 3 \text { DAS followed by } \\
\text { halosulfuron methyl } 75 \mathrm{WG}\left(90 \mathrm{~g} \mathrm{ha}^{-1}\right) \text { at } 25 \text { DAS }\end{array}$ & $\begin{array}{c}68.2^{*} \\
(86.0)^{\star *}\end{array}$ & 9.64 & 7.44 & 1373 \\
\hline Weed free check & $\begin{array}{c}69.0^{*} \\
(87.0)^{\star *}\end{array}$ & 10.37 & 8.34 & 1627 \\
\hline Unweeded check & $\begin{array}{c}70.7^{*} \\
(89.0)^{\star *}\end{array}$ & 8.02 & 6.05 & 1251 \\
\hline SEd & 2.5 & 0.37 & 0.27 & 49 \\
\hline$C D(P=0.05)$ & NS & 0.79 & 0.57 & 103 \\
\hline
\end{tabular}

* Data are arcsine transformed value.

** Date in parentheses are original value.

Table 4: Extended weed control of herbicides on succeeding blackgram.

\begin{tabular}{|c|c|c|}
\hline Treatments & $\begin{array}{c}\text { Weed } \\
\text { density } \\
\left(\text { No. }_{\text {pot }}{ }^{-1}\right)\end{array}$ & $\begin{array}{c}\text { Weed dry } \\
\text { weight } \\
\left(\mathrm{g} \mathrm{pot}^{-1}\right)\end{array}$ \\
\hline Atrazine 50 WP $\left(0.25 \mathrm{~kg} \mathrm{ha}^{-1}\right)$ at 3 DAS followed by one hand weeding at 25 DAS & $\begin{array}{c}4.26^{*} \\
(17.67)^{\star *}\end{array}$ & $\begin{array}{c}3.51^{*} \\
(11.83)^{\star *}\end{array}$ \\
\hline Pendimethalin $38.7 \mathrm{EC}\left(1 \mathrm{~kg} \mathrm{ha}^{-1}\right)$ at 3 DAS followed by one hand weeding at 25 DAS & $\begin{array}{c}4.63^{*} \\
(21.00)^{\star *}\end{array}$ & $\begin{array}{c}3.63^{*} \\
(12.74)^{\star *}\end{array}$ \\
\hline Atrazine $50 \mathrm{WP}\left(0.25 \mathrm{~kg} \mathrm{ha}^{-1}\right)$ at 3 DAS followed by tembotrione $34.4 \mathrm{SC}\left(120 \mathrm{~g} \mathrm{ha}^{-1}\right)$ at 25 DAS & $\begin{array}{c}2.41^{*} \\
(5.33)^{\star *}\end{array}$ & $\begin{array}{c}1.79^{*} \\
(2.72)^{\star *}\end{array}$ \\
\hline Pendimethalin $38.7 \mathrm{EC}\left(1 \mathrm{~kg} \mathrm{ha}^{-1}\right)$ at $3 \mathrm{DAS}$ followed by tembotrione $34.4 \mathrm{SC}\left(120 \mathrm{~g} \mathrm{ha}^{-1}\right)$ at $25 \mathrm{DAS}$ & $\begin{array}{c}2.53^{*} \\
(6.00)^{* *}\end{array}$ & $\begin{array}{c}2.09^{*} \\
(3.87)^{* *}\end{array}$ \\
\hline Atrazine $50 \mathrm{WP}\left(0.25 \mathrm{~kg} \mathrm{ha}^{-1}\right)$ at 3 DAS followed by halosulfuron methyl $75 \mathrm{WG}\left(90 \mathrm{~g} \mathrm{ha}^{-1}\right)$ at $25 \mathrm{DAS}$ & $\begin{array}{c}3.34^{*} \\
(10.67)^{\star *}\end{array}$ & $\begin{array}{c}2.50^{*} \\
(5.76)^{\star *}\end{array}$ \\
\hline Pendimethalin $38.7 \mathrm{EC}\left(1 \mathrm{~kg} \mathrm{ha}^{-1}\right)$ at 3 DAS followed by halosulfuron methyl $75 \mathrm{WG}\left(90 \mathrm{~g} \mathrm{ha}^{-1}\right)$ at $25 \mathrm{DAS}$ & $\begin{array}{c}3.53^{*} \\
(12.00)^{\star *}\end{array}$ & $\begin{array}{c}2.57^{\star} \\
(6.10)^{\star *}\end{array}$ \\
\hline Weed free check & $\begin{array}{c}1.74^{*} \\
(2.67)^{\star *}\end{array}$ & $\begin{array}{c}1.27^{*} \\
(1.12)^{\star \star}\end{array}$ \\
\hline Unweeded check & $\begin{array}{c}5.64^{*} \\
(31.33)^{* *}\end{array}$ & $\begin{array}{c}4.67^{*} \\
(21.33)^{\star *}\end{array}$ \\
\hline SEd & 0.23 & 0.11 \\
\hline$C D(P=0.05)$ & 0.48 & 0.23 \\
\hline
\end{tabular}

*- Data are $\sqrt{x+0.5}$ transformed value.

** Date in parentheses are original value. 
Preceding Maize Crop Herbicide Residual Effect on Germination, Growth and Vigour of Succeeding Blackgram

Table 5: Influence of residual herbicides on succeeding blackgram.

\begin{tabular}{|c|c|c|c|c|}
\hline Treatments & $\begin{array}{l}\text { Plant height } \\
\quad(\mathrm{cm})\end{array}$ & $\begin{array}{l}\text { Leaves } \\
\left(\text { No plant }^{-1}\right)\end{array}$ & $\begin{array}{l}\text { Dry matter } \\
\text { production }\left(g_{\text {plant }}^{-1}\right)\end{array}$ & $\begin{array}{c}\text { No. of root } \\
\text { nodules }\end{array}$ \\
\hline $\begin{array}{l}\text { Atrazine } 50 \mathrm{WP}\left(0.25 \mathrm{~kg} \mathrm{ha}^{-1}\right) \text { at } 3 \text { DAS followed by } \\
\text { one hand weeding at } 25 \text { DAS }\end{array}$ & 28.3 & 13.14 & 1.12 & 8.11 \\
\hline $\begin{array}{l}\text { Pendimethalin } 38.7 \mathrm{EC}\left(1 \mathrm{~kg} \mathrm{ha}^{-1}\right) \text { at } 3 \mathrm{DAS} \text { followed by } \\
\text { one hand weeding at } 25 \mathrm{DAS}\end{array}$ & 28.0 & 12.05 & 1.10 & 8.25 \\
\hline $\begin{array}{l}\text { Atrazine } 50 \mathrm{WP}\left(0.25 \mathrm{~kg} \mathrm{ha}^{-1}\right) \text { at } 3 \text { DAS followed by } \\
\text { tembotrione } 34.4 \mathrm{SC}\left(120 \mathrm{~g} \mathrm{ha}^{-1}\right) \text { at } 25 \mathrm{DAS}\end{array}$ & 29.5 & 14.51 & 1.17 & 9.64 \\
\hline $\begin{array}{l}\text { Pendimethalin } 38.7 \mathrm{EC}\left(1 \mathrm{~kg} \mathrm{ha}^{-1}\right) \text { at } 3 \mathrm{DAS} \text { followed by } \\
\text { tembotrione } 34.4 \mathrm{SC}\left(120 \mathrm{~g} \mathrm{ha}^{-1}\right) \text { at } 25 \mathrm{DAS}\end{array}$ & 29.4 & 13.55 & 1.17 & 9.49 \\
\hline $\begin{array}{l}\text { Atrazine } 50 \mathrm{WP}\left(0.25 \mathrm{~kg} \mathrm{ha}^{-1}\right) \text { at } 3 \mathrm{DAS} \text { followed by } \\
\text { halosulfuron methyl } 75 \mathrm{WG}\left(90 \mathrm{~g} \mathrm{ha}^{-1}\right) \text { at } 25 \mathrm{DAS}\end{array}$ & 28.9 & 14.06 & 1.15 & 9.52 \\
\hline $\begin{array}{l}\text { Pendimethalin } 38.7 \mathrm{EC}\left(1 \mathrm{~kg} \mathrm{ha}^{-1}\right) \text { at } 3 \text { DAS followed by } \\
\text { halosulfuron methyl } 75 \mathrm{WG}\left(90 \mathrm{~g} \mathrm{ha}^{-1}\right) \text { at } 25 \mathrm{DAS}\end{array}$ & 28.7 & 14.06 & 1.14 & 8.34 \\
\hline Weed free check & 30.1 & 14.73 & 1.20 & 10.32 \\
\hline Unweeded check & 24.1 & 13.07 & 1.09 & 8.89 \\
\hline SEd & 1.63 & 0.75 & 0.03 & 0.62 \\
\hline$C D(P=0.05)$ & 3.47 & 1.59 & 0.08 & 1.31 \\
\hline
\end{tabular}

plant height $(30.1 \mathrm{~cm})$, dry matter production $\left(1.15 \mathrm{~g} \mathrm{plant}^{-1}\right)$ and number of leaves (14.06) was recorded in weed free check and it was on par with $\mathrm{T}_{3}$. Effective utilization of natural resources increase the photosynthetic activity of blackgram resulted in higher plant height, leaf area and dry matter production. This result is agreement with the findings of Kumar et al. (2015).

\section{Number of root nodules plant ${ }^{-1}$}

Nodulation is a distinctive feature of legume crops. Number of root nodules reflect the quantity of biological nitrogen fixation, which is a main feature for fertility restoration. Residual effect of herbicides did not influence the number of root nodules in succeeding blackgram. However the highest number of root nodules was recorded in weed free check and it was on par with pre emergence atrazine at $0.25 \mathrm{~kg} \mathrm{ha}^{-1}$ followed by post emergence tembotrione at 120 $\mathrm{g} \mathrm{ha}^{-1}$, pre emergence atrazine at $0.25 \mathrm{~kg} \mathrm{ha}^{-1}$ followed by post emergence halosulfuron methyl $90 \mathrm{~g} \mathrm{ha}^{-1}$ and pre emergence pendimethalin at $1.0 \mathrm{~kg} \mathrm{ha}^{-1}$ followed by post emergence tembotrione at $120 \mathrm{~g} \mathrm{ha}^{-1}$. Residual rich nutrient status enhance the nodulation and improve the symbiotic relationship of the host legume (Singh et al., 2017).

\section{CONCLUSION}

Weed free practices was not feasible among farmers due to high cost incurred in weeding. Hence farmers used the chemical weed management practices. From the experimental results it can be concluded that application of preceding herbicides on maize did not influence the germination and any phytotoxity residual effect on succeeding blackgram. In maize- blackgram cropping system application of atrazine $0.25 \mathrm{~kg} \mathrm{ha}^{-1}$ followed by tembotrione $120 \mathrm{~g} \mathrm{ha}^{-1}$ in maize registered the highest grain yield and benefit cost ratio of preceding maize and recorded the extended weed control, highest plant height, dry matter production and seedling vigour index of succeeding blackgram.

\section{ACKNOWLEDGEMENT}

I sincerely acknowledge the Tamil Nadu State Council for Science and Technology (TNSCST) in successful completion of my research through their help and support.

\section{REFERENCE}

Abdul Baki, A.A. and Anderson, J.D. (1973). Vigor determination in soybean seed by multiple criteria. Crop Science. 13: 630-633.

Adarsh, S., Jacob, J. and Giffy, T. (2019). Role of pulses in cropping systems: A Review. Agricultural Reviews. 40(3): 185-191.

Chand, M., Singh, S., Dharam, B., Singh, N. and Kumar, V. (2014). Halosulfuron methyl: A new post emergence herbicide in India for effective control of Cyperus rotundus in sugarcane and its residual effects on the succeeding crops. Sugar Technology. 16(1): 67-74.

Dekker, J. (2015). Soil weed seed banks and weed management. Journal of Crop Production. 3(12): 139-166.

Ellis, R.H. and Roberts, E.H. (1981). The quantification of ageing and survival in orthodox seeds. Seed Science and Technology. 9: 373-409.

Gomez, K.A. and Gomez, A.A. (1984). Statistical procedures for agricultural research: John Wiley \& Sons, Inc., New Yark, USA.

Gharde, Y., Singh, P.K., Dubey, R.P. and Gupta, P.K. (2018). Assessment of yield and economic losses in agriculture due to weeds in India. Crop Protection. 107: 12-18.

Horowitz, M. (1976). Application of bioassay techniques to herbicide investigations. Weed Research. 16(4): 209-215.

Houge, E.J. and Neilsen, G.H. (1988). Effects of excessive annual applications of ternacil, diuron, simazine and dichlobenil on vigor, yield and cation nutrition of young apple trees. Canadian Jounal Plant Science. 68: 843-850. 
Indiastat. (2019). Online database. in:httpp://www.indiastat.com.

Korav, S., Dhaka, A.K., Singh, R., Premaradhya, N. and Reddy, C.G. (2018). A study on crop weed competition in field crops. Journal of Pharmacognosy and Phytochemistry. 7(4): 3235-3240.

Kumar, S., Bhatto, M.S., Punia, S.S. and Punia, R. (2015) Bioefficacy of herbicides in blackgram and their residual effect on succeeding mustard. Indian Journal of Weed Science. 47(2): 211-213.

Nazreen, S., Subramanyam, D., Sunitha, N. and Umamahesh, V. (2018). Seedling vigour index and productivity of greengram as influenced by pre-and post-emergence herbicicdes applied to maize. Journal of Pharmacognosy and Phytochemistry. 7(3): 584-587.

Rao, V.S. (1983). Principles of weed science. Oxford and IBH. Publishers, Co. Ltd., New Delhi: 19-80.

Robinson, D.E. (2008). Atrazine accentuates carryover injury from mesotrione in vegetable crops. Weed Technology. 22(4): 641-645.
Singh, M., Kumar, S., Kumar, R. and Rajesh, K. (2014). Effect of post emergence herbicides on weed control and yield of field pea and their residual effect on succeeding sorghum and blackgram crop. Legume Research- An International Journal. (37): 387-394.

Singh, S., Pathak, R. and Pancholy, A. (2017). Role of Root Nodule Bacteria in Improving Soil Fertility and Growth Attributes of Leguminous Plants Under Arid and Semiarid Environments. In book: Rhzobium Biology and Biotechnology. 39-60.

USDA. (2020). https://apps.fas.usda.gov/psdonline/circulars/production.

Verma, V.K., Tewari, A.N. and Dhemri, S. (2009). Effect of atrazine on weed management in winter maize-greengram cropping system in central plain zone of Uttar Pradesh. Indian Journal of Weed Science. 41(1 and 2): 41-45.

Yaduraju, N.T., Sharma, A.R. and Rao, A.N. (2015). Weeds in Indian Agriculture Problems and prospects to become self sufficient. Indian Farming. 65(7): 02-06. 